\title{
REFLEXIVIDADE METAPRAGMÁTICA SOBRE O CINEMA DE ALMODÓVAR NUMA INTERAÇÃO ONLINE: INDEXICALIDADE, ESCALAS E ENTEXTUALIZAÇÃO
}

\section{METAPRAGMATIC REFLEXIVITY ABOUT ALMODÓVAR 'S CINEMA ON AN ONLINE INTERACTION: INDEXICALITY, SCALES AND ENTEXTUALIZATION}

\author{
Clarissa Gonzalez ${ }^{* 1}$ \\ Luiz Paulo da Moita Lopes ${ }^{* * 2}$
}

\section{RESUMO}

Este artigo analisa uma postagem publicada no site espanhol Dos Manzanas, que predica Pedro Almodóvar como "pedagogo da realidade LGBT", e alguns dos comentários que esta suscita. Interessa-nos estudar a reflexividade metapragmática que essa pedagogia produz numa discussão online que avalia se a cinematografia almodovariana projeta uma fachada (GOFFMAN, [1967] 2011) favorável para o coletivo em questão. Para tal, focamos em processos de indexicalidade, de entextualização e escalares na construção de significados. $\mathrm{O}$ que se observa é que os textos fílmicos, ao serem entextualizados no referido site de notícias LGBT, mobilizam escalas, que inspiram posicionamentos das/dos participantes. Se, por um lado, tais posicionamentos questionam privilégios heteronormativos (BUTLER, 1990), por outro resvalam em essencialismos nada estratégicos (SPIVAK, 1988; BUTLER, 1990).

Palavras-chave: indexicalidade; escalas; entextualização.

\section{ABSTRACT}

This article analyzes a post published in the Spanish website Dos Manzanas, which qualifies Pedro Almodóvar as a "pedagogue of the LGBT reality", and some of the comments it brings about. Our purpose is to study the metapragmatic reflexivity that this pedagogy produces in an online discussion that assesses if the Almodovarian cinematography projects a face (GOFFMAN, [1967] 2011) favorable to the collective in question. We focus on

* Universidade Federal do Rio de Janeiro, Rio de Janeiro (RJ), Brasil. gonzalezclariss@gmail.com

** Universidade Federal do Rio de Janeiro, Rio de Janeiro (RJ), Brasil. moitalopes1@gmail.com

1. Sou grata à Capes pela bolsa $\mathrm{PNPD} / 2013$ que permitiu o desenvolvimento desta pesquisa junto ao Programa Interdisciplinar de Linguística Aplicada da UFRJ, sob a orientação do Prof. Dr. Luiz Paulo da Moita Lopes.

2. Agradeço ao CNPq pela Bolsa de Produtividade que propiciou esta pesquisa (CNPq 302989/20137), assim como o auxílio à pesquisa da FAPERJ (E-26/110.065/2012) e do CNPq (Edital Universal 470547/2012-0). 
indexicality, entextualization and scalar processes in meaning construction. What is observed is that when the film texts are entextualised in the LGBT news site, they inspire positionings that, on the one hand, question heteronormative privileges (BUTLER, 1990), and on the other, slip into non-strategic essentialisms (SPIVAK, 1988; BUTLER, 1990). Keywords: indexicality; scales; entextualization.

\section{INTRODUÇÃO}

Pedro Almodóvar é um dos cineastas em atividade mais debatidos dentro e fora da academia. Sua obra tem motivado diversas reflexões sobre as pragmáticas e metapragmáticas que envolvem performances de gênero e sexualidade que fogem de padrões heteronormativos.

No campo de estudos da linguagem, há investigadores (FELIPPE, 2004; VELOSO, 2012), que, como nós (GONZALEZ \& MOITA LOPES, 2015, 2016), recentemente debruçaram-se sobre seus filmes.

Neste artigo, focamos no modo como situações e personagens criados por Almodóvar são metapragmaticamente enquadrados e avaliados em uma postagem que predica o cineasta como "pedagogo da realidade LGBT" e nos comentários que esta suscita ao ser publicada no site espanhol Dos Manzanas, voltado para audiências LGBT.

Considerando três das principais bandeiras levantadas por esse coletivo - a igualdade de direitos, a normalização social e a visibilidade de todas sociabilidades que compõem a sigla $\mathrm{LGBT}^{3}$-, trataremos de indexicalmente identificar Discursos ${ }^{4}$ (GEE, 2004) que as/os participantes entextualizam ao julgarem situações e personagens das narrativas fílmicas, bem como opiniões de outras/outros participantes a respeito. Além disso, enfocamos como ao fazê-lo, as/os participantes, muitas vezes, estabelecem uma comparação entre dois níveis escalares: o da ficção cinematográfica e o das experiências que vivenciam, refletindo metapragmaticamente sobre ambos. Isso nos dá instrumentos para avaliar os efeitos de tal reflexividade tendo como referência a mencionada pedagogia LGBT almodovariana.

3. Na interação que analisamos, de 2009, usa-se a sigla LGTB (na Espanha, o T vem antes do B), que equivale a LGBT, forma mais comumente usada no Brasil, de maneira que optamos por mantê-la assim neste artigo. Internacionalmente, no entanto, adota-se hoje uma versão mais abrangente da sigla: LGBTTQIA+. Além de Lésbicas, Gays, Transexuais e Bissexuais, incluem-se também Transgêneros, Queer, Intersexuais, Assexuados e Outras/Outros (+).

4. Usamos discurso, com letra minúscula, para referenciar os enunciados proferidos, enquanto Discurso, em maiúscula, remete às ideologias e aos conhecimentos que nos orientam (GEE, 2004, p. 15). 
Esta preocupação com a reflexividade, como salientam Moita Lopes (2013a, 2013b, 2015), Blommaert e Rampton (2011), permeia uma sociolinguística contemporânea que foca em como os sujeitos fazem uso da linguagem e os efeitos de tais usos no mundo social em meio a uma globalização altamente reflexiva, que nos convida a refletir, continuamente, sobre nós mesmos, nossas práticas e nosso estar no mundo. Por mais que esta atividade reflexiva sempre tenha nos constituído como sujeitos sociais, não se tratando de algo novo, no momento contemporâneo nos deparamos com uma reflexividade mais intensa (GIDDENS, BECK \& LASH, 1997).

Em tempos líquidos (BAUMAN, 2001) e superdiversos (VERTOVEC, 2007), as 'verdades' que a Modernidade ofertava ruem. São muitas as tensões e questionamentos que os fluxos contemporâneos ensejam. São fruto desses tempos, as práticas transidiomáticas (JACQUEMET, 2005), a convergência digital (JENKINS, 2008), bem como os diversos trânsitos e atravessamentos sócio-laborais, 'identitários', geopolíticos e geoculturais (BLOMMAERT, 2010). Um panorama como este, em que o estável cede passo ao contingente, levando-nos a operar em meio a incertezas, faz com que estejamos em contínuo exercício reflexivo. Seja para assimilarmos o que nos rodeia e produzirmos sentido sobre nossas práticas (metapragmática), seja para nos posicionarmos e agirmos (pragmática).

Se compreendemos a metapragmática como uma "reflexão sobre a pragmática ou para além dela", tendo em conta o que o prefixo 'meta', de origem grega, indica "refletir sobre si, para além de", percebe-se a relação indissolúvel entre pragmática e metapragmática e a interseção dessa noção com a de reflexividade. Usualmente definida como uma forma de enquadrar a realidade ou de elaborar instruções para que esta seja enquadrada conforme se deseja, a metapragmática aponta para o modo como nos colocamos no mundo enquanto sujeitos sociais, evidenciando os Discursos que nos guiam. Por isso, há autores (SILVA, PEREIRA \& ALENCAR, 2014, por exemplo) que tecem analogias entre metapragmática e ideologia, entre metapragmática e processos de contextualização. Nós, neste artigo, também a contemplaremos sob este prisma, destacando, sobretudo, seu caráter reflexivo e indexical.

Coadunamo-nos com Blommaert e Rampton (2011, p. 10), que, ao problematizarem o conhecimento compartilhado e seus atravessamentos indexicais, conectam a reflexividade metrapragmática com "a forma como as pessoas entendem a própria comunicação e a dos outros". Ressaltam ainda que o agir metarreflexivo, especialmente no que tange à forma de enquadrar uma dada situação socioculturalmente e à leitura que se deseja que os outros façam dela, bem 
como a relação entre linguagem e prática semiótica é um dos principais focos de interesse da Sociolinguística e da Antropologia Linguística na contemporaneidade.

Estas duas áreas do conhecimento entendem que o agir no mundo se dá em um campo sensível, permeado por índices que localizam nossas ações dentro de um arcabouço sociocultural, que conecta tal agir (pragmática) com o entendimento local/translocal sobre este produzido (metapragmática). E que, mais do que apontar para o que fazemos (pragmática), esta reflexividade evidencia como o fazemos metapragmaticamente (SILVA, PEREIRA \& ALENCAR, 2014).

Fechando este breve parêntese, julgamos importante ressaltar que nos distanciamos de uma Sociolinguística mais tradicional, que privilegia padrões, usos tácitos da linguagem e variedades linguísticas (sobre essa visão, checar: BLOMMAERT \& RAMPTON, 2011; MOITA LOPES, [2006] 2016, p. 230-232). Apostamos em uma vertente da Sociolinguística que entende a linguagem como prática social (GEE, 1990; MOITA LOPES, [2006] 2016, 2013a) e assumimos o desafio de analisar uma interação online registrada em outro tempo (2009), país (Espanha) e idioma (castelhano), que nos leva a operar em meio aos atravessamentos linguísticos, históricos e culturais característicos dos novos tempos globalizados. Outro diferencial que ofertamos são os diálogos 'indisciplinares' (MOITA LOPES, [2006] 2016) entre áreas do conhecimento, como a Sociolinguística, a Antropologia Linguística, a Pragmática e a Comunicação Audiovisual, tendo como pano de fundo o ativismo LGBT.

Por se apoiarem em reivindicações que essencializam as 'identidades' correspondentes às letras que compõem a sigla, há vertentes do ativismo LGBT que diferem da nossa aposta político-epistemológica, uma vez que entendemos o gênero como performance e não como essência. De forma que, para fundamentar teoricamente essa discussão, recorremos brevemente às Teorias Queer (BUTLER, 1990, 1999, 2004; PRECIADO, [2003] 2011; WILCHINS, 2004) e logo detalhamos o conceito de 'identidade' (BUTLER, 1990; HALL, 2013) do qual nos valemos. Na sequência, versaremos sobre 'essencialismo estratégico' (SPIVAK, 1988), ou seja, a possibilidade de se fazer uso apenas político e pontual das 'identidades' em jogo (BUTLER, 1990), com o propósito de debater essa alternativa em face ao que tem lugar na interação. A seguir, apresentamos o site em que a interação analisada ocorreu (Dos Manzanas), especificamos o instrumental teórico-analítico a ser empregado e efetuamos a análise.

Em termos de ferramental teórico-analítico, empregamos os construtos de indexicalidade (SILVERSTEIN, 2003), entextualização (SILVERSTEIN \& URBAN, 1996; BAUMAN \& BRIGGS [1990] 2009) e escalas (CARR \& LEMPERT, 2016). 
Este desenho de investigação nos permitirá identificar como as/os participantes, ao se posicionarem na interação sobre as performances de gênero e sexualidade de personagens das narrativas fílmicas contempladas, avaliam a pedagogia almodovariana, bem como os efeitos desta em suas práticas. Dito de outra maneira: este desenho de investigação tem por função sinalizar o exercício de reflexividade metapragmática levado a cabo pelos participantes.

\section{TEORIAS QUEER: HERANÇAS DA MODERNIDADE EM XEQUE}

A Modernidade e seu ideal positivista, ancorado num estruturalismo de viés representacional que esquematiza os saberes, delimitando rígidas barreiras entre eles (MOITA LOPES, [2006] 2016), distancia-se das práticas para manter imaculado seu ideal cientificista e puro, blindando o que institui como conhecimento legítimo das 'contaminações' do uso e do entorno sociocultural (BAUMAN \& BRIGGS, 2003). Como resultado, estabelecem-se padronizações assépticas e hegemônicas, bem como deslegitimações do que destas diferem.

Pondo em xeque essa herança moderna, as Teorias Queer se ocupam de desconstruir o que tais padronizações convertem em norma. Para tal, partem de duas noções foucaultianas: uma delas diz respeito à maneira como Foucault ([1969] 2008) concebe o Discurso, compreendendo-o como o conjunto de práticas que constituem o que descrevem, enquanto a outra remete à forma como regimes de saber-poder-ser estão indelevelmente imbricados (FOUCAULT, [1969] 2008, [1972] 1984).

Do mesmo modo que um conhecimento puro só existiria sob a forma de 'dogma' platônico, ou seja, como algo que pertence a uma instância superior à qual apenas poucos eleitos conseguem aceder, as performances de gênero e sexualidade, igualmente, pertenceriam à dimensão do inquestionável ao se conceber a biologia como destino (BUTLER, 1990; PENNYCOOK, 2007).

Por conta disso, as Teorias Queer põem em xeque a falácia do determinismo biológico, desconstruindo ideologias que nele se escoram para legitimar performances e, por conseguinte, 'identidades' heteronormativamente orientadas, produto de práticas ritualizadas que fazem com que certas formas de existir e agir pareçam 'naturais' e 'coerentes' (BUTLER, 1990). Estas, compreendidas como inerentes à condição humana, convertem-se em algo contra o que não cabem questionamentos, posto que diria respeito a uma suposta 'essência' biológica compartilhada por todos os seres humanos. 
Não por casualidade, o combate à heteronormatividade (BUTLER, 1990; WILCHINS, 2004) ganha centralidade nas Teorias Queer. Prerrogativas heteronormativas e o que delas advém imobilizam o sujeito (inclusive sociolinguisticamente), enclausuram-no em determinada 'espécie' (FOUCAULT, [1976] 1999) ao rotularem algumas de suas práticas. Cabe lembrar que o pertencimento a uma espécie implica a realização de certas performances discursivoidentitárias e afetivo-sexuais, sendo as hetero-orientadas as únicas que gozam de legitimidade social.

$\mathrm{O}$ ato de nomear, portanto, teria o poder de produzir subjetividades, de constituir o que descreve: quando se atrela uma determinada categoria 'identitária' a alguém, a engrenagem performativa, que se abastece da repetição, é capaz de fazer com que esse ato adquira materialidade subjetivante e produza efeitos estigmatizantes. Nesse movimento taxonômico, institui-se um mecanismo de controle que se ocupa de catalogar as mais diversas práticas, legitimando algumas e deslegitimando outras, instaurando e mantendo desigualdades (BAUMAN \& BRIGGS, 2003).

Se consideramos o significativo peso da sexualidade na projeção de uma 'identidade social', na determinação de uma 'espécie', na conformação de um tipo reconhecível de sujeito (FOUCAULT, [1976] 1999; WORTHAM, 2005), não é difícil constatar que certas práticas, como as afetivo-sexuais, podem adquirir mais destaque que outras. Estas, junto à designação de gênero e a interseccionalidades de raça e classe, definirão como o sujeito passa a existir socialmente (MELO \& MOITA LOPES, 2014) e prevalecerão em processos de categorização identitária.

Para fugir desse esquema excludente, heteronormativamente instaurado e mantido, o qual só reconhece como legítimas certas performances, e, por conseguinte, certas 'identidades', o pensamento pós-estruturalista, em especial o de viés foucaultiano, fonte de inspiração para as Teorias Queer, sugere que se opere com uma concepção pós-identitária de sujeito (BUTLER, 1999; PRECIADO [2003] 2011).

Tendo tal concepção em tela, algumas/alguns autoras/autores optaram por radicalizar e abdicar do conceito de 'identidade', posto que esta sempre cercearia o indivíduo. Cameron e Kulick (2003, p. 14), por exemplo, resolveram apostar na noção de "sujeitos desejantes". Em contrapartida, outros, como Bucholtz e Hall (2004), argumentaram que não seria possível renunciar à noção de 'identidade', uma vez que, em nossas práticas sociais, nós a produzimos de forma incessante: projetamos uma 'identidade' ao nos posicionarmos ante qualquer interlocutor e evento, ao mesmo tempo em que atribuímos uma 'identidade' às pessoas com as 
quais interagimos. Essas pessoas, igualmente, projetam suas 'identidades' sobre nós e nos constroem de acordo com os efeitos de sentido que nossas práticas ‘identitárias’ produzem neles/nelas.

$\mathrm{O}$ debate acerca do essencialismo estratégico, que esboçaremos mais adiante, também evidencia o quão difícil resultaria prescindir da 'identidade'. Para Bucholtz e Hall (2004), não se trata de negá-la, mas de reconsiderar o que se entende por 'identidade': em lugar de concebê-la como uma instância que prefigure o sujeito e lhe suponha um determinado modus operandi, as autoras sugerem que se contemple a 'identidade' como fruto dos regimes semióticos mobilizados, localmente, nas interações. Segundo tal ponto de vista, as 'identidades', percebidas como fluidas e em constante configuração, são projetadas e negociadas, preservadas ou ressignificadas em práticas situadas.

\section{2. 'IDENTIDADES' COMO PERFORMANCE}

Sempre que interagimos, inevitavelmente nos posicionamos (GOFFMAN, [1979] 2002) e nos projetamos 'identitariamente'. Tais posicionamentos, balizados pela ordem moral (BERGMAN, 1998) do contexto que os compreende, são assumidos tendo em vista a maneira como interpretamos uma dada situação e a fachada que desejamos projetar (GOFFMAN, [1967] 2011), ou seja, a imagem social que desejamos construir para nós mesmos ou para um grupo/coletivo ao qual pertencemos (GOFFMAN, [1967] 2011; OSTERMANN, 2003), lembrando que esta pode ser ratificada ou não por aquelas/aqueles (GOFFMAN, [1979] 2002) com os quais interatuamos.

Em outras palavras: somos seres de contexto (MOITA LOPES, [2006] 2016) e as performances discursivo-identitárias que desempenhamos em nossas práticas interacionais fazem com que, ininterruptamente, estejamos produzindo 'identidades' para nós mesmos e para os outros, além de, concomitantemente, sermos encapsulados pelas 'identidades' que projetam sobre nós e encapsularmos nossa(o) interlocutor(a) na 'identidade’ que sobre ela/ele projetamos.

Fato é que a 'identidade’ é constantemente (res) significada e (re)negociada na interação, estando em sintonia com as múltiplas semioses em jogo, que, por sua vez, estão atreladas às ordens morais que atravessam nossas performances e à forma como valoramos certas formas de existir/estar no mundo, de performar a 'identidade’. Nesse sentido, 'identidades’ devem ser entendidas como: 
produtos/efeitos de performances corporais e linguísticas que repetem, reiteram ou subvertem discursos ${ }^{5}$ dominantes que trancafiam as posições de sujeito em binarismos, como homem/ mulher, hetero/homo. (BORBA, 2015, p. 91)

Precisamente por serem "efeitos de performances corporais e linguísticas", 'identidades' não preexistem às práticas sócio-discursivas (BUTLER, 1990; MOITA LOPES, [2006] 2016, 2013a), mas surgem a reboque destas. Tal teorização implode o determinismo biológico, segundo o qual as performances de gênero são definidas com base nos caracteres sexuais exteriores do indivíduo (BUTLER, 1990; PRECIADO, [2003] 2011), e a heteronormatividade, que estipula que sexo, gênero e desejo devem convergir de forma cis $^{6} /$ heterossexual (BUTLER, 1990). Portanto, conceber 'identidades' como performance supõe dar vazão à ideia de que toda e qualquer 'identidade' é forjada nas múltiplas semioses que permeiam as práticas sócio-discursivas nas quais nos engajamos (HALL, 2013). Tais semioses podem liberar o sujeito de seguir executando determinadas performances ritualizadas de gênero e sexualidade ou atá-lo a elas. Em outras palavras: em nossas práticas situadas, podemos questionar ou revalidar certos regimes de verdade que nos orientam.

Em face a esta visão, segundo a qual 'identidades' são produzidas/negociadas em ato, não podemos ignorar as relações de poder que envolvem a construção 'identitária', uma vez que:

o que caracteriza [...] o poder que analisamos aqui é que ele coloca em jogo relações entre indivíduos (ou entre grupos). Pois não devemos nos enganar: se falamos do poder das leis, das instituições ou das ideologias, se falamos de estruturas ou mecanismos de poder, é apenas na medida em que supomos que alguns exercem poder sobre outros. (FOUCAULT, 2010, p. 240)

Se entendemos a 'identidade' como produto de semioses que advêm da nossa práxis enquanto sujeitos sociais (BUCHOLTZ \& HALL, 2004; HALL, 2013), dos nossos posicionamentos (GOFFMAN, [1979] 2002), da forma como produzimos sentido acerca do que performamos - e do que performam para nós - nas interações das quais participamos, logramos nos desgarrar da carga essencializante que a noção de 'identidade' arrasta, tornando-a operacionalmente dinâmica e capaz de captar as relações de poder/controle que envolvem sua negociação, bem como seus usos e efeitos, sejam estes essencialistas ou estratégicos.

5. Nesta citação, respeitamos a forma como o autor escreveu a palavra 'discurso', mantendo-a com a inicial em minúscula.

6. O prefixo 'cis' remete às pessoas que atuam conforme a identidade de gênero que lhes é assignada por conta de seus caracteres sexuais exteriores: se tiver pênis, deve performar o gênero de forma masculina. Se tiver vagina, deve performar o gênero de forma feminina 


\title{
3. ESSENCIALISMO ESTRATÉGICO E ATIVISMO LGBT
}

\begin{abstract}
O sexo (os órgãos chamados 'sexuais', as práticas sexuais e também os códigos de masculinidade e de feminilidade, as identidades sexuais normais e desviantes) entram no cálculo do poder, fazendo dos discursos sobre o sexo e das tecnologias de normalização das identidades sexuais um agente de controle da vida.
\end{abstract}

(Preciado [2003] 2011, p. 11)

Para esquivar as estratégias de captura postas em prática por agentes de controle e evitar o risco de naturalizar performances discursivo-identitárias, apostamos em uma noção pós-identitária de sujeito (BUTLER, 1999; BORBA, 2015) e só concebemos operar com 'identidades' essencializadas se este for o último recurso cabível para obter ganhos políticos (SPIVAK, 1988; BUTLER, 1990), para defender aquelas/aqueles que sofrem os efeitos materiais mais avassaladores de práticas heteronormativas.

O "essencialismo estratégico" contempla a possibilidade de nos valermos de certas categorias 'identitárias' para fazer uso político e pontual das mesmas (SPIVAK, 1988), especialmente quando o que está em jogo é a conquista de direitos sociais e a condenação de atos de violência perpetrados contra sociabilidades não normativas. Cabe ressaltar que não se pretende que tal uso seja extensivo ou prescritivo, de forma que não se trata de atribuir fixidez essencializante às 'identidades', uma vez que elas são forjadas e negociadas nas interações. Limitar-nos-íamos, portanto, a evocar a 'identidade' para combater a exclusão/violência e conquistar direitos/garantias de cidadania para aqueles que não se enquadram em padrões heteronormativos.

Quando nos propomos a 'queerizar' o conceito de 'identidade', entendendo-o como fruto de semioses situadas, dos efeitos de sentido interacionalmente produzidos em diálogo com Discursos orientadores, regimes de verdade e ordens morais que norteiam nossas práticas e perpassam a forma como valoramos socioculturalmente as experiências que nos circundam, pode parecer contraditório defender qualquer tipo de essencialismo. No entanto, como os recursos semióticos são disponibilizados de forma assimétrica e o acesso aos mesmos se dá de forma diferenciada (BLOMMAERT, 2005), certas hierarquizações ganham materialidade e, por conseguinte, determinadas formas de saber-poder-ser se sobrepõem a outras. Logo, haverá situações em que certos sujeitos, por uma questão de sobrevivência social, quiçá não tenham outra alternativa além de se escorar na 'identidade' e dela fazer uso estratégico, uma vez que, para existirem socialmente, precisam se tornar 
inteligíveis (BUTLER, 1990), ou seja, necessitam se tornar tipos reconhecíveis de sujeitos (FOUCAULT, [1976] 1999; WORTHAM, 2005). E isto só ocorre, como sinaliza Butler $(1990,2004)$, a partir do momento em que o indivíduo é generificado, recordando que, para gozar de certos privilégios sociais, este deve seguir a cartilha heteronormativa.

Como nos recorda Miskolci (2011), a expressão "essencialismo estratégico" foi cunhada por Spivak, mas Foucault ([1976] 1999) já havia previsto que se pudesse fazer uso tático e pontual da 'identidade', ou seja, que se reivindicasse, em circunstâncias específicas, um certo essencialismo como parte de uma estratégia política para fazer frente à forma como a heteronormatividade impõe socialmente certas performances de gênero e sexualidade como as únicas legítimas.

Logo, mesmo que muitas das lutas do coletivo LGBT sejam travadas em nome da 'identidade', entendemos que tal artifício é, em certas ocasiões, necessário: afinal, é através deste que certas vozes se fazem escutar, especialmente aquelas cujos sujeitos que as ecoam não seguem, em suas performances de gênero e sexualidade, preceitos heteronormativos. Portanto, ainda que nos orientemos por uma forma de contemplar o gênero e a sexualidade que questiona e desconstrói prefigurações 'identitárias' (PINTO, 2013), entendemos como útil fazer uso político e estratégico de alguns essencialismos (BUTLER, 1990) em momentos-chave.

Uma vez esclarecidas as principais diretrizes teóricas que orientam esta pesquisa, localizaremos, à continuação, o site LGBT Dos Manzanas e detalharemos o instrumental teórico-analítico a ser utilizado. Em seguida, efetuaremos a análise.

\section{DOS MANZANAS}

O Dos manzanas (Duas maçãs), em seu espaço no Facebook, define-se como:

um site que pretende seguir de perto as principais notícias relacionadas a lésbicas, gays, transexuais e bissexuais, assim como outras da atualidade política, social e cultural. Tudo isso com a participação dos leitores como eixo de discussão, debate e reflexão. ${ }^{8}$

7. O título do site alude a uma declaração perniciosa de Ana Botella em 2005: "As maçãs não são peras. Se somamos uma maçã e uma pera, nunca teremos duas maçãs" [Tradução nossa]. Mulher do ex-presidente espanhol Aznar, Botella, que posteriormente assumiria a prefeitura de Madri, num posicionamento contrário à aprovação da lei que permitia uniões civis entre pessoas do mesmo sexo na Espanha, comparou inadvertidamente combinações de frutas com relações homoafetivas. Fonte: Jornal Público $<\underline{\text { http://www.publico.es/espana/perlas-dialecticas-ana-botella.html }>\text { [acesso: 26/06/2016] }}$

8. Tradução: nossa. 
O site, atualizado com frequência diária, conta com oito itens no menu principal: España (Espanha), Derechos (Direitos), Política, Internacional, Activismo (Ativismo), Sociedad (Sociedade), Cultura/Ocio (Cultura/Lazer) e Secciones (Seções). O texto que motivou a interação online a ser analisada foi publicado na seção Opinião, dentro do submenu Cine (Cinema), que se encontra na aba Cultura/ Lazer, e foi assinado por um autor, aqui mantido em anonimato, que colaborou com o Dos Manzanas entre 2009 e 2013, geralmente escrevendo matérias relacionadas a temas culturais.

Em atividade no ambiente online desde novembro de 2005, o Dos manzanas conta com web e páginas em redes sociais (Facebook, Twitter, Instagram, Google +, You Tube, Flickr). Um dos pesquisadores, que já manteve contato com colaboradores do site e acompanha discussões nele propostas, às vezes delas participando, foi quem sugeriu que se analisasse a postagem "Pedro Almodóvar, pedagogo da realidade LGBT $^{\prime \prime}$, publicada dia 28 de abril de 2009, bem como alguns dos comentários por ela motivados. O primeiro foi publicado duas horas e 24 minutos depois de o texto ter sido lançado e o último, de um total de 28 comentários, foi registrado no dia 30 de abril de 2009, às 11:44, horário peninsular espanhol. Dada a considerável extensão das postagens, fizemos um recorte que privilegiou o texto que motivou a interação, bem como comentários subsequentes a este relacionados.

\section{INSTRUMENTAL TEÓRICO-ANALÍTICO}

Tendo em tela nosso objetivo de analisar como participantes que se engajam numa interação online refletem metapragmaticamente sobre a pedagogia de Almodóvar e avaliam se esta projeta uma fachada favorável para o coletivo LGBT, cabe, primeiramente, recuperar a definição do termo. Goffman ([1967] 2011, p. 13), que o cunhou, define fachada ou face/trabalho de face como "o valor social positivo que uma pessoa efetivamente reivindica para si (...) Uma imagem do eu delineada em termos sociais aprovados."

Logo, para entender de que modo $\mathrm{D} /$ discursos são entextualizados, indexicalizados e perspectivizados ao serem proferidos, recorremos a outros três construtos teórico-analíticos que nos resultarão úteis na análise de dados:

- Entextualização: é o processo pelo qual um texto passa quando, uma vez extraído do seu contexto primeiro, precipita em novos contextos

9. Tradução: nossa. 
(BAUMAN \& BRIGGS, [1990] 2009). Nesse movimento de descontextualização e recontextualização, de citação e repetição, textos, segundo Silverstein e Urban (1996), que podem entrar nessa dinâmica infinitas vezes, são ressignificados;

- Indexicalidade: é a propriedade que o signo linguístico tem de apontar para significados que excedem seu contexto de enunciação. Este construto nos permite identificar como um determinado signo, ao ser empregado em uma dada interação, por conta da repetição de usos, conecta-se com sentidos sociohistoricamente absorvidos (SILVERSTEIN, 2003), o que chamamos acima de Discursos (ver nota 2);

- Escalabilidade: é uma ferramenta usada para relacionar as diferentes instâncias do D/discurso, a forma como o situacional (micro/token) dialoga com o extra-situacional (macro/type). Precisamente por isso, guarda estreita relação com a noção de indexicalidade. Também evidencia as relações de poder que atravessam a produção discursiva (BLOMMAERT, 2010), como os "limites espaço-temporais dos objetos de análise" são manufaturados (CARR \& LEMPERT 2016, p. 6) e de que modo estes operam transições escalares, atravessando diferentes espaços-tempos, por exemplo (BLOMMAERT, 2010). Dessa forma, a noção de escala possibilita analisar como a linguagem forja dimensões da vida social ao estabelecer perspectivas, posicionamentos, comparações, avaliações, categorizações etc. por meio da linguagem (CARR \& LEMPERT, 2016).

\section{PEDAGOGIA ALMODOVARIANA E FACHADA LGBT SOB ANÁLISE}

Dividida em dois excertos, começamos a análise com a postagem que incitou uma discussão online sobre a pedagogia almodovariana no site Dos Manzanas. Em lugar de transcrevê-la, optamos por inserir uma impressão de tela. Logo, esta será analisada e, na sequência, faremos o mesmo com o segundo excerto, dedicado à interação que da postagem advém.

Nos dois excertos, privilegiamos a reflexividade metapragmática que subjaz à visão das/dos participantes sobre o cinema de Almodóvar e a forma como este não só as/os afeta em suas práticas discursivo-identitárias, mas também ao coletivo LGBT como um todo. 


\section{Excerto 1: Pedro Almodóvar, pedagogo de la realidad LGTB}

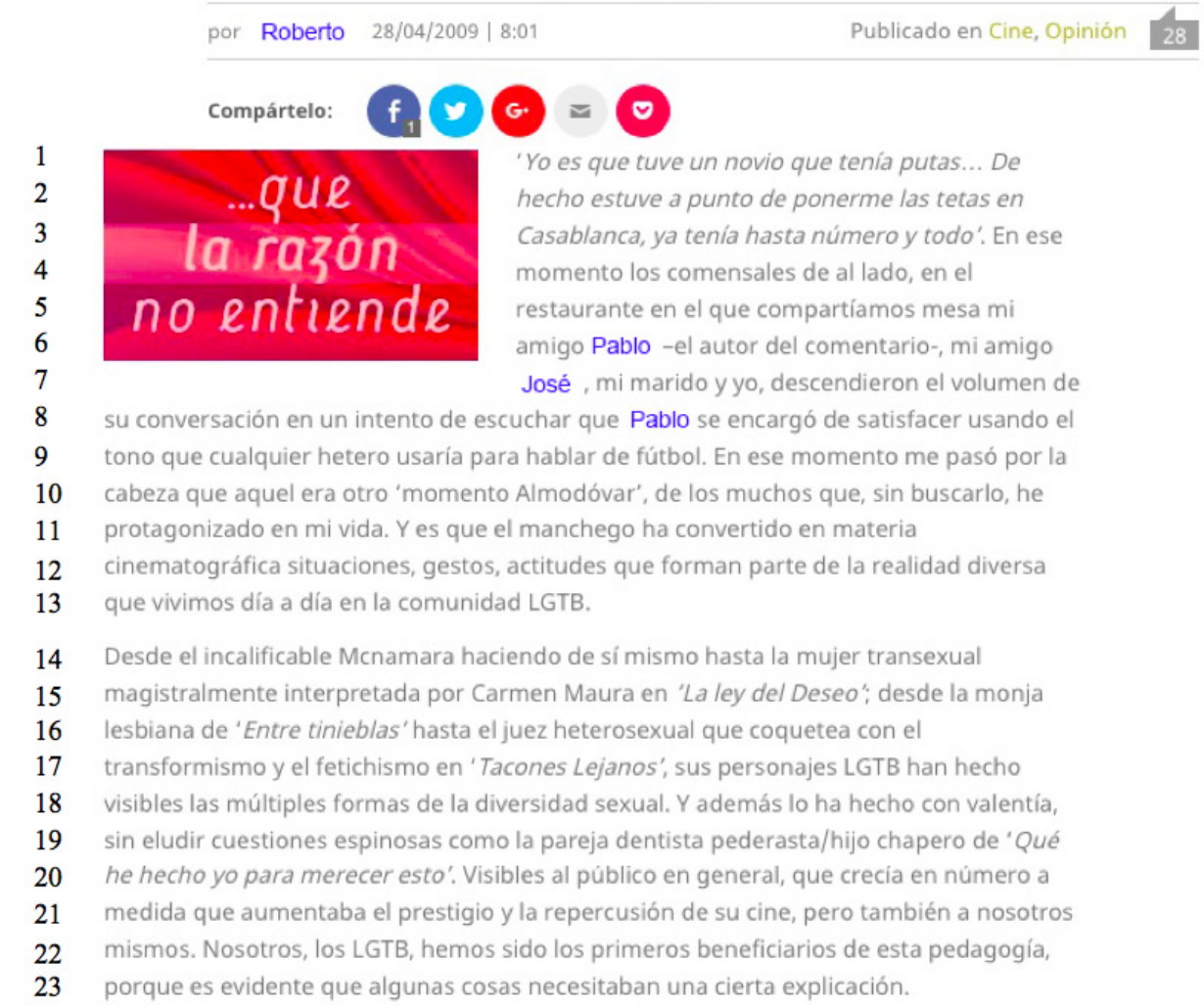


24 Cuando la dictadura franquista agonizaba, mi amigo Pablo se echó 'un novio que tenía

25 putas'. No se sentía mujer, pero como le gustaban los hombres y los únicos LGTB con los

26 que se había sentido identificado alguna vez eran los travestis (mucho más que con los

27 'respetables' clientes de éstas o con su propio novio, por muy bueno que fuera en la

28 cama), su confusión resulta razonable. En una época en que a los homosexuales no se les

29 puertas que se abrían difícilmente podían volver a cerrarse. Hoy en día, a pesar de las

30 dificultades con las que nos seguimos encontrando, los LGTB tenemos muchos más

31 referentes en los que reconocernos. Estos referentes -unos más acertados y otros

32 menos- proceden en su mayoría de los medios de comunicación (la educación, por

33 desgracia, aún no ha asumido plenamente su responsabilidad en este asunto). Y sin duda

34 alguna, uno de los que más certeramente ha mostrado estos modelos en el cine ha sido

35 nuestro Pedro Almodóvar.

36 Más de una vez me he preguntado qué habría sido de mi amigo Pablo si, contrariamente

37 a su verdadera identidad de género, se hubiera puesto las tetas. Y se me ha pasado por

38 la cabeza el personaje interpretado por Toni Cantó en 'Todo sobre mi madre'. Vaya por

39 delante que conozco la diferencia entre orientación sexual e identidad de género. Sé que

40 hay mujeres transexuales que se sienten atraídas por otras mujeres. A lo mejor este es el

41 caso de Lola. Pero también es posible que fuera simplemente, un hombre confundido.

42 'Nos pusimos las tetas juntas', dice la Agrado, pero es evidente que no han corrido la

43 misma suerte. Porque, aunque no se puede decir que a la Agrado la vida le haya sonreído

44 (menudos palos se ha llevado), al menos es feliz en su cuerpo y se considera 'auténtica'.

45 Por el contrario, Lola ha llevado una vida infeliz y autodestructiva. Sospecho que no se

46 siente mujer, las palabras de Manuela (Cecilia Roth) parecen confirmarlo 'Exceptuando el 
47

48

49

50

51

52

53

54

55

56

57

58

59

60

61

62

63

par de tetas, en lo demás el marido no habia cambiado tanto': Y una sociedad como la de entonces no ofrecía muchas posibilidades ni mucho margen de maniobra a quienes, en ese laberinto de feria que describía antes, querían desandar el camino tomado.

Da un poco de vértigo preguntarse cuántas 'Lolas' hay. Cuántas vidas truncadas en cuántas diferentes formas. Espero que sean muchos más los que, como mi amigo Pablo, fuera por el azar, fuera por miedo o por todo lo contrario, fuera por una íntima revelación, pudieron desarrollarse como personas completas y poder llamarse 'auténticos'.

Y en cuanto a Pedro, a nuestro cineasta más premiado internacionalmente, mi agradecimiento por las decenas de personajes LGTB a los que hemos visto reir, llorar, amar, odiar, enloquecer, traicionar, perdonar, sentir, morir... en sus películas. Por esos personajes en que nos hemos mirado y reconocido, aquellos cuyos pensamientos eran un eco de los nuestros. Personajes e historias, que nos juntaron por docenas en los cines, haciéndonos visibles también en el patio de butacas. Porque en cualquier estreno de Almodóvar, cualquier heterosexual que tuviera la sensación de que aquellos personajes no eran más que un 'invento' del director, no tenía mas que esperar al final, para ver filas enteras de LGTB emocionados, divertidos e identificados.

Roberto ${ }^{10}$ inicia sua narrativa com uma entextualização ("eu tive um namorado que tinha putas..."11), um gancho para narrar um episódio do qual ele, junto ao marido e um casal de amigos, José e Pablo, teria participado. Os quatro jantavam num restaurante quando Pablo fez a referida confissão e atraiu as atenções dos ali presentes, que abaixaram o volume em que mantinham suas conversas para ouvilo. Roberto, ao comparar o tom de voz que Pablo usa para narrar suas peripécias homoeróticas ao de um heterossexual falando de futebol, estabelece uma escala de categorias em oposição. Logo Roberto predica a cena como um dos muitos "momentos almodóvarianos" que viveu, refletindo metapragmaticamente tanto sobre a prática discursiva que está narrando quanto sobre outras levadas a cabo na ficção cinematográfica. A referida entextualização põe, assim, em perspectiva o 'mundo gay' ou 'LGBT' (no qual homens têm maridos, colocam seios em Casablanca etc.), o qual será submetido a um exercício escalar. Roberto sugere, ademais, que Almodóvar transpõe elementos de uma escala, a da observação de situações, gestos e atitudes, para outra, a escala da ficção: "É que o manchego ${ }^{12}$ converteu em matéria cinematográfica situações, gestos e atitudes que formam parte da realidade diversa

10. Os nomes das/dos participantes foram modificados de forma a mantê-las/los em anonimato.

11. Este trecho, assim como todos os demais usados na análise, foram traduzidos por nós. Os mesmos também constam em espanhol, como pode ser verificado nas impressões de tela.

12. Refere-se a Almodóvar, proveniente da região de Castela-Mancha, na Espanha. 
que vivemos dia a dia na comunidade LGBT". Outro ponto que merece destaque neste primeiro parágrafo é o pertencimento do narrador à referida comunidade, indexicalizado desde o inicio na referência ao marido, na entextualização de uma fala que perspectiviza a narrativa (um namorado que tinha putas e desejava colocar seios), no movimento escalar embutido na categorização da fala de Pablo (tom similar ao de um heterossexual), e no uso da primeira pessoal do plural ("vivemos").

No parágrafo seguinte, Roberto referencia alguns dos personagens de Almodóvar ("Desde o inqualificável McNamara...") e, em um movimento escalar, predica-os como LGBT. Sua familiaridade para com eles o posiciona como alguém que detém conhecimento sobre os mesmos e gabarito para atestar que estes "tornaram visíveis múltiplas formas de diversidade sexual", servindo também para indexicalizar o quão antenado está com as reivindicações LGBTs, afinal, tal declaração entextualiza dois Discursos muito recorrentes em comunidades LGBT: o da diversidade e o da visibilidade (WILCHINS, 2004). Logo Roberto posiciona Almodóvar como "pedagogo" e conclui esse parágrafo predicando e avaliando as/ os LGBTs como "os primeiros beneficiários desta pedagogia".

No terceiro parágrafo, o autor reentextualiza parte da citação com a qual abrira sua postagem ("um namorado que tinha putas") e, ato seguido, situa seu amigo Pablo numa determinada escala espaço-temporal: por meio das referências "quando a ditadura franquista agonizava", produz um contexto que remete à suspensão de direitos e liberdades (referência à "ditadura") e a um país num momento sóciohistórico específico (a Espanha nos últimos anos do franquismo) em que as/os homossexuais ainda eram bastante perseguidas/os (ARNALTE, 2003; MELERO SALVADOR, 2010). Quando repete a mesma citação com que inicia o texto, desta vez sem incluir o pronome pessoal e o verbo na primeira pessoa do singular, Roberto converte o que antes era uma narrativa direta e em primeira pessoa ("eu tive um namorado que tinha putas..."), mesmo que não protagonizada por quem a narra, em uma narrativa indireta, feita em terceira pessoa, ao incluir, diante de "um namorado que tinha putas", outro sujeito e verbo ("Pablo arranjou"). Tal movimento nos recorda que "o "eu" não tem história própria que não seja também a história de uma relação" (BUTLER, [2005] 2015, p. 18).

No que tange a essas entextualizações feitas por Roberto, cabe um breve parêntese: estas, além de corroborarem o caráter subjetivo-relacional das 'identidades', produzem efeitos diversos: ao entextualizar a fala do amigo pela primeira vez, Roberto se vale desta para ilustrar o que predica como "momento Almodóvar", posicionando-se como alguém que teria vivido momentos assim, o que supõe dizer que, por meio de projeções reiteradas de determinadas situações 
fílmicas, os "momentos Almodóvar" ganham materialidade e passam a pertencer à instância do vivido. Eis aí uma transposição escalar: "momentos almodovarianos" passam da ficção para a experiência pessoal. Já a segunda entextualização da mesma fala é usada como gancho para o narrador dar mais detalhes sobre seu amigo Pablo. Cumpre também a função de introduzir a comparação entre duas escalas espaçotemporais (BLOMMAERT, 2010) no que tange a referentes/modelos: "hoje em $\mathrm{dia}^{13}$, apesar das dificuldades que seguimos encontrando, nós LGBT temos muitos mais referentes nos quais podemos nos reconhecer".

$\mathrm{Na}$ linha 28, Roberto, em alusão à possibilidade de colocar silicone nos seios, qualifica tal desejo como "confusão", o que pode indexicalizar tanto menosprezo às modificações corpóreas das quais muitas/os transgêneros se valem (afinal, trata-se 'apenas' de uma confusão), como também uma forma diferenciada de dimensionar performances de homo e transerotismo. E apesar de sugerir um processo de identificação ("os únicos LGBT com os quais se identificou alguma vez eram as travestis"), Roberto não reconhece como factível um possível desejo de redesignação de gênero parcial expresso por seu amigo (colocar seios). Mesmo que seu discurso também possa ser lido como um clamor por reconhecimento/visibilidade de sociabilidades gays, resulta paradoxal negar reconhecimento a outrem (travestis) e requerê-lo para si enquanto gay, afinal, como nos recorda Butler (2004, p. 14), "o desejo é sempre um desejo de reconhecimento" e "os termos que nos permitem sermos reconhecidos como humanos são articulados socialmente". De forma que, ao negar reconhecimento a performances de travestilidade/transexualidade, Roberto ajuda a subtrair humanidade daquelas(es) que as desempenham num exercício escalar que ou forja um ser inferiorizado ou o invisibiliza.

Invisibilidade, por certo, é o tema do qual Roberto trata à continuação (linhas 28-30): "numa época em que os homossexuais não eram vistos, o descobrimento da sua própria sexualidade levava a uma série de tentativas, quase sempre a cegas". Segundo Melero Salvador (2010), realmente escasseavam referentes homoeróticos: as únicas performances de homoerotismo autorizadas pelo franquismo, que censurava as demais nos meios de comunicação de massa, eram as caricatas, alvo de ridicularização e/ou punição social. Fora das telas, muitas/muitos homossexuais foram implacavelmente perseguidos (ARNALTE, 2003), tendo algumas/alguns sido submetidos a choques e demais tratamentos "de cura". Performances de homossexualidade, porém, não eram as únicas cruelmente repreendidas.

O quarto parágrafo requer especial atenção. Roberto o inicia com um questionamento: "Mais de uma vez, eu me perguntei o que teria sido do meu amigo

13. Referência à Espanha democrática de 2009, época em que o texto foi publicado. 
Pablo se, contrariando a sua verdadeira identidade de gênero, tivesse colocado silicone nos seios". Tal declaração deixa brecha para inferir que se o amigo colocasse silicone nos seios, estaria traindo sua identidade de gênero e projeta nova escala de oposição: haveria uma identidade de gênero verdadeira e outra que não o é. Esta declaração, ademais, indexicaliza Discursos orientadores que entendem a biologia como destino (BUTLER, 1990; PENNYCOOK, 2007) e não reconhecem o caráter performativo e paródico de gênero (BUTLER, 1990), supondo, assim, a existência de uma essência comum a todos. Em nome dessa suposta essência, legisla-se sobre os usos do prazer (FOUCAULT, [1984] 1998) e demarca-se como e por quem determinadas performances córporeo-identitárias devem ser encenadas (BUTLER, 1990).

Nas linhas 39 e 40, Roberto explicita que o episódio envolvendo seu amigo o remete a Lola, personagem que, depois de empreender redesignação de gênero parcial (coloca silicone nos seios), engravida uma freira em Tudo sobre minha mãe. Logo assegura, num exercício explícito de reflevidade metapragmática, que "sabe da diferença entre orientação sexual e identidade de gênero" e, de forma a demonstrar familiaridade com o tema, referencia: "Sei que existem mulheres transexuais que se sentem atraídas por outras mulheres". Porém, apesar de admiti-lo, faz nova menção a um suposto estado de confusão ("também é possível que fosse simplesmente um homem confundido"). Uma das interpretações possíveis que se pode inferir dos sentidos mobilizados por Roberto aponta para um dimensionamento desigual das performances desempenhadas pelas 'identidades' que a sigla LGBT abarca: além de insistir na tese da confusão (a persistência em não reconhecer como efetivo o desejo de redesignação de gênero de seu amigo, traz para a escala do visível apenas desejos homoeróticos), inferioriza performances não hegemônicas de travestilidade/ transexualidade, como as desempenhadas por Lola. Essa inferiorização é fruto de uma construção discursiva ancorada em escalas de categorias em oposição: enquanto Agrado, que executa performances transheterossexuais, é "feliz em seu corpo e se considera autêntica", Lola, que encena performances translésbicas ${ }^{14}$, é "infeliz e autodestrutiva".

Neste mesmo parágrafo, há outro ponto a ser destacado que reforça essa hipótese. Foquemos na entextualização de uma fala proferida pela personagem Manuela acerca de Lola: "Se não fosse pelo par de seios, diria que [meu] marido não mudou tanto". Enquanto Manuela atesta que a 'aquisição' de um par de seios, por si só, não supôs uma mudança no comportamento do marido, que

14. Forma de nomear as mulheres transexuais que, depois da redesignação de gênero, relacionam-se sexual e afetivamente com outras mulheres. 
continuava mulherengo, Roberto, ao entextualizá-la, sugere que Lola não "se sentia mulher", que não era uma transexual 'verdadeira', afinal, sua redesignação parcial de gênero não fez com que sexo, desejo e identidade de gênero convergissem heteronormativamente (BUTLER, 1990). Lola continuava sentindo-se atraída por mulheres mesmo tendo adquirido um corpo 'parcialmente feminino'. Esta entextualização evidencia como um texto pode ser ressignificado ao precipitar em novos contextos (BAUMAN \& BRIGGS, [1990] 2009) e indexicaliza discursos de senso comum ao equiparar travestilidade/transexualidade a "sentir-se mulher". Tal idealização é tendenciosa em pelo menos quatro níveis: primeiro porque o autor não detalha o que entende por "mulher"; segundo porque ele parte do preceito de que todas as travestis/transexuais compartilham um desejo comum (sentir-se mulher). Terceiro porque entende que só há uma forma de sentir-se mulher, o que supõe uma essencialização das performances de feminilidade. E quarto porque, dentre as muitas performances de feminilidade possíveis, não contempla que uma travesti/ transexual possa desempenhar a de lésbica. Esta é apagada pelo autor.

O quinto parágrafo é dedicado ao estabelecimento de um paralelo entre duas escalas: a da narrativa fílmica (em especial, a trajetória da personagem Lola) e a das "vidas truncadas de diferentes formas", conforme Roberto afirma. O autor, depois de lançar uma pergunta retórica ("Quantas Lolas existem?"), a qual evidencia a reflexividade metapragmática que pontua seu discurso, insinua que seu amigo, ao desistir de colocar silicone nos seios, escapou de ter o mesmo destino trágico de Lola. Como se isso tivesse bastado para livrá-lo de ter uma "vida truncada" e garantido que se desenvolvesse como pessoa "completa" e "autêntica". O uso da predicação 'autêntica', mesmo entre aspas simples, aponta para Discursos que atrelam a autenticidade de gênero ao determinismo biológico, algo que as Teorias Queer se encarregam de desconstruir (BUTLER, 1990, 1999, 2004; WILCHINS, 2004).

No último parágrafo, Roberto, posicionando-se como porta-voz do coletivo, depois de agradecer "pelas dezenas de personagens LGBT", conclui seu texto justificando o título deste, que projeta Almodóvar como "pedagogo da realidade LGBT": no seu entendimento, os personagens do cineasta que não performam gênero e sexualidade de forma heteronormativa, permitiram que muitas das pessoas que realizam as performances que a sigla LGBT engloba se sentissem representadas. Almodóvar teria lhes 'instruído' e dado visibilidade.

No debate que se segue a essa postagem, basicamente se discute se Almodóvar produz uma fachada positiva para a comunidade LGBT, se a pedagogia do cineasta resulta útil às/aos participantes que analisam seus efeitos pragmáticos- 
metapragmáticos. Tendo isso em conta, neste segundo excerto, analisaremos comentários que versam sobre tal questão, dando continuidade à trajetória textual que o texto de Roberto, bem como as narrativas fílmicas, seguem ao serem entextualizados pelas/pelos participantes. Dos 28 comentários que totalizam esta interação, escolhemos dez subsequentes e omitimos três que fugiam ao nosso foco de pesquisa, sinalizados com reticências entre parênteses. Tal como no primeiro excerto, efetuamos a análise depois de expor as impressões de tela com os comentários selecionados.

\section{Excerto 2:}

\section{(...)}

Napoleón 28/04/2009|10:39

01 Bueno, básicamente estoy de acuerdo con el tono del artículo. Mi primera

02 película de Almodovar la vi en los antiguos Alphaville, cuando aún hacía el

03 bachillerato, junto a varios de mis compis. Fue "Laberinto de pasiones", una

04 película que hoy sería mucho más polémica que en el momento de su estreno,

05 cuando aún estaban vivas las imágenes del último intento de golpe de estado

06 en nuestro país. La peli sólo me gustó a mi, a mis compis de barriada periférica

07 les escandalizó mucho.

08 En fin, sin discutir el fondo del artículo, yo si reprocharía una sola cosa a

09 Almodovar, y es su distanciamiento del movimiento asociativo LBGT. Hace muy

10 poquito hablabamos aquí de la figura de Boris Izaguirre, creo que el además

11 de ser un gay militante en su ámbito profesional, también puso su granito de

12 arena en favor del ámbito reivindicativo organizativo, con gestos y con su

13 presencia por ejemplo en el orgullo (o en la protesta ante la sede del PP hace

14 algunos meses).

15 Por lo demás, desde luego, el universo recreado por Almodovar en su

16 cinematografía es sin duda una aportación capital a la visibilización del ámbito

17 LGBT y a su normalización social. Eso, desde luego, es indiscutible. CNTP 28/04/2009|11:12

18 Confieso que el artículo me ha dejado parado un rato reflexionando... lo cual

19 creo que es muy bueno. Por lo menos, por eso, gracias. 
Dill $\quad 28 / 04 / 2009 \mid 1: 17$

20 Almodóvar representa una parte de la realidad LGTB.

21 Yo no me he sentido nunca representado por su cine (que tampoco puedo

22 decir que yo sea un experto, ni mucho menos).

23 El problema viene de hacer estereotipos. Hay tantos gays distintos como

24 personas, y eso no lo entienden quienes hablan despectivamente de "cine de

25 maricones y travestis" que además merecen el mismo respeto que cualquiera

26 en tanto que son personas.

Lan 28/04/2009 | 2:41

27 " "sus personajes LGTB han hecho visibles las múltiples formas de la diversidad

28 sexual."

29 Sus personajes son decadentes, engullidos por la droga, la prostitución y la

30 delincuencia... ¿Cúando Almodovar ha sacado un personaje LGTB realmente

31 digno? Pienso que nunca lo ha hecho porque él se ha sentido así, sometido a

32 una sociedad donde te asignaba un rol y no dejaba resquicio para escapar de

33 él.

34 En mi opinión, flaco favor hace al colectivo LGTB mostrrando una y otra vez los

35 estereotipos más extremistas de una realidad que tambien posee la

36 heterosexualidad pero que se ha utilizado única visión injusta de la realidad

37 LGTB.

38 Un ejemplo de mis referentes favoritos: Alan Turing padre de la informática,

39 de la inteligencia artificial y de las redes neuronales... fue condenado por

40 homosexualidad y tratado con hormonas que le destrozaron organos internos,

41 le salieron pechos y le dejaron impotente para curar su homosex desde toda la

42 caridad cristiana 


\section{(...)}

Chelsea $\quad 28 / 04 / 2009 \mid$ 4:02

43 Aunque no me guste todo lo de Almodóvar y alguna vez haya sido crítico con

44 él cuando así lo he creído, el comentario anterior me parece fuera de lugar.

45 Pedro Almodóvar, como director y, por tanto, autor con una visión

46 exclusivamente suya, hace el cine que le da la gana con los personajes y

47 situaciones que le da la gana. Sin que tenga que rendir explicaciones a nadie y,

48 mucho menos, al colectivo LGTB. Porque, que yo sepa, no es portavoz de

49 nadie.

50 Podríamos discutir hasta la saciedad las razones que le llevan a retratar estos

51 personajes y sus circunstancias, pero independientemente de éstas, no

52 necesita justificarse. Pero jojo!, ni él ni cualquier creador/a LGTB.

53 Sin embargo, me resulta curioso que sólo le critiques por sus películas y

54 personajes y dejes fuera del objetivo de la cámara su vida y su actitud con el

55 tema LGTB. Porque, muchas veces, no hace falta hacer discurso alguno. Basta

56 que el quiera entender, entienda.

Croissant 28/04/2009| 4:11

57 Y abundando en lo que ha dicho Chelsea , añadiré que los personajes de

58 Almodóvar son por lo general personajes límite que viven situaciones límite,

59 tanto Igtb como hetero.

60 Querer hacer de sus películas una lectura perjudicial para la comunidad Igtb es

61 una solemne tontería. 
Nelson 28/04/2009| 4:45

62 Esta mañana leía yo en otro blog que Curri Valenzuela había incluido a Pedro

63 Almodóvar en su (ejem) libro 100 personajes que hunden España, y en el

64 número 2 nada menos (el número 1 es, oh sorpresa, Zapatero). La razón por la

65 cual Almodóvar hunde España de modo tan eminente para la (ejem ejem)

66 periodista es que, según parece, Valenzuela va mucho a comprar el periódico a

67 Nueva York, y cuando realiza dicha operación no se olvida nunca de decirle al

68 quiosquero que ella es española; entonces, oh horror de los horrores, el

69 quiosquero, que indefectiblemente es buen conocedor de la filmografía

70 almodovariana, la mira con cara de vicio -siempre según ella-, pues asume que

71 todos los españoles son tan depravados como los que salen en las pelis del

72 manchego...

73 No sé por qué, el comentario deLan("flaco favor hace [Almodóvar] al colectivo

74 LGTB mostrando una y otra vez los estereotipos más extremistas") me ha

75 hecho pensar en el (ejem ejem ejem) argumento de la presentadora de

76 TeleEspe (al fin y al cabo, donde una dice "los españoles", el otro dice "el

77 colectivo LGTB").

Iván 28/04/2009|5:05

78 Pues yo estoy de acuerdo con Lan Y encima el autor del post califica de valentía

79 el hecho de poner a un dentista pederasta....¿valentía de qué? Supongo que la

80 misma que sacar un personaje violador o un asesino. ¿O es que quizá le

$\mathbf{8 1}$ parece positivo el relacionar homosexualidad y pederastia? Quién sabe,

82 después de tanto despropósito...

Croissant 28/04/2009|5:19

83 Pues volvemos, una vez más, a lo de siempre.

84 En "Kika" (para mí la peor película de Almodóvar, aunque esto no viene al

85 caso), sale durante largo rato una violación, y el violador es un personaje

86 presidiario y con pocas luces.

87 Hemos de colegir entonces que Almodóvar le ha hecho un flaco favor al

88 colectivo heterosexual, ¿no? 
89 Nelson no me negarás que la escena de Curry Valenzuela comprando el

90 periódico en Nueva York y el kiosquero poniéndole caritas lascivas tiene

91 bastante de almodovariana...

\section{Roberto 28/04/2009|5:32}

92 Napoleón : Algunas películas de Almodóvar hoy serían un escándalo

93 mayúsculo, estoy contigo.

94 CNTP. Me alegro de que te haya hecho pensar.

95 Dill : La verdad es que su carrera no ha terminado, supongo que

96 aún le queda muchos personajes en la chistera. Personalmente, me 'intriga'

97 mucho el personaje interpretado por Rubén Ochandiano, Ray X (el de 2008, no

98 el de 1994), ¿retrata a 'un nuevo tipo de gay'?

99 Lan, tienes todo el derecho a no estar de acuerdo, al fin y al cabo esto es sólo

100 mi opinión. No obstante, te podría nombrar algún personaje LGTB

101 almodovariano bastante equilibrado. Huma Rojo, por ejemplo, la actriz

102 Iesbiana de 'Todo sobre mi madre'.

103 Iván, a mí me parece valiente coger algo que muchos utilizan para atacarnos y

104 presentarlo con sinceridad y sin falsa moral en una película (magistral por

105 cierto)

106 Lulu, Croissant, Chelsea, Nelson : Gracias por vuestras aportaciones

107 Un saludete.

Em seu primeiro comentário, Napoleón opera duas transições escalares espaço-temporais. O primeiro nos transporta à Espanha de 1982, quando estreou nos cinemas o filme Labirinto de paixões, de Almodóvar. O segundo, a 1981, quando a jovem democracia espanhola se viu ameaçada por nova tentativa de golpe ${ }^{15}$. $\mathrm{O}$ participante se vale destas transições escalares para colocar em perspectiva o conturbado momento sócio-histórico em que Almodóvar realiza seus primeiros filmes. Logo, para mensurar o impacto destes, opera com escalas de comparação: enquanto seus vizinhos se escandalizaram com o filme, ele não. Conclui sua postagem estabelecendo prós e contras: valora positivamente o "universo recriado por Almodóvar", reconhecendo que este contribui para "a visibilidade LGBT e sua normalização social", mas queixa-se de que o cineasta não se engaja com a causa LGBT em sua vida pessoal.

O comentário de CNTP destaca os efeitos reflexivos que a postagem de Roberto inspira ("levou à reflexão") e os avalia positivamente ("acho que isso é

15. O ditador Francisco Franco falece no dia 20 de novembro de 1975. Finda o franquismo, tendo início um novo período democrático na Espanha, que se vê ameaçado por nova tentativa de golpe no dia 23 de fevereiro de 1981 . 
muito bom"). O seguinte comentário começa com um remanejamento escalar da afirmativa de Roberto: "Almodóvar representa uma parte da realidade LGBT", modaliza Dill, que, em seguida, promove uma transição escalar ao tecer uma apreciação metonímica: o problema da (suposta) estereotipificação de personagens LGBT empreendida por um cineasta (Almodóvar, no caso) reside em se tomar a parte pelo todo ("cinema de maricas e travestis"), o que, segundo Dill, embaça a percepção de que "existem tantos tipos diferentes de gays como de pessoas".

Lan inicia o quarto comentário entextualizando um trecho da postagem de Roberto que faz alusão positiva aos personagens de Almodóvar ("tornaram visíveis múltiplas formas de diversidade sexual"), mas os avalia de maneira oposta, qualificando-os como "decadentes". Logo, num movimento que põe em evidência o exercício de reflexividade metapragmática que leva a cabo, Lan faz uma pergunta retórica: questiona se Almodóvar já teria dado a conhecer algum personagem LGBT "digno" e responde à própria pergunta: "penso que nunca". Na sequência, Lan credita o fato de Almodóvar retratar personagens "engolidos pela droga, prostituição e delinquência" ao fato de o cineasta se sentir "submetido a uma sociedade que te atribuía um papel e não deixava margem para escapar dele", estabelecendo um paralelo entre o que trafega na escala ficcional e o que sucede na escala não ficcional.

Outra leitura possível é a de que Lan relaciona performances homoeróticas a práticas estigmatizantes (consumo de drogas, prostituição e delinquência), indexicalizando, assim, Discursos de senso comum, que o cinema espanhol ajudou a propagar durante o franquismo. Performances de homoerotismo quando transpostas para a tela, além de serem estigmatizadas, levando ao riso ou inspirando pena, eram patologizadas e/ou punidas física, psicológica e socialmente (MELERO SALVADOR, 2010). Os poucos filmes espanhóis que abordavam o tema de forma séria e tinham sua exibição autorizada pelo regime ditatorial geralmente não contavam com desenlaces felizes, pelo menos para aqueles personagens que performavam o gênero e a sexualidade de forma não hegemônica (MELERO SALVADOR, 2010). O cinema de Almodóvar, de alguma maneira, faz uma análise crítica de alguns dos possíveis efeitos performativos destas narrativas, sem deixar de, em contrapartida, operar ressignificações ao, muitas vezes, fugir de clichês heteronormativos ou parodiá-los. Há de se ter em conta, ademais, que a prostituição e a delinquência não são unicamente associadas a performances trans/bi/homoeróticas ${ }^{16}$ em seus filmes.

16. Em Átame, por exemplo, o protagonista, que performa heterossexualidade, ao sair da cadeia, sequestra uma mulher pela qual havia se apaixonado antes de ir preso e a mantém refém dentro da própria casa dela. 
Depois de Lan finalizar seu texto qualificando que há fachadas "melhores" que a de Almodóvar para endossar a imagem social (GOFFMAN, [1967] 2011; OSTERMANN, 2003) do coletivo LGBT e citar Alan Turing ${ }^{17}$ como exemplo, Chelsea, autor do quinto comentário, admite não gostar de tudo de Almodóvar e se autopredica como "crítico". Esta ressalva indica que sua avaliação será justa e, metapragmaticamente, dá instruções de como deve ser encarada (imparcialmente). Em seguida, qualifica o comentário anterior como "fora de lugar", defende que Almodóvar goza de liberdade para contemplar "personagens e situações como bem desejar" e afirma que o cineasta "não é porta-voz de ninguém" em alusão ao comentário de Lan e ao texto que inspira a interação, posicionando-se com relação à questão que novamente ganha centralidade neste debate: julgar se a cinematografia almodovariana constrói ou não uma boa fachada para a comunidade LGBT. Depois de eximir Almodóvar desse tipo de responsabilidade/compromisso, referencia o fato de que "poderíamos discutir até a exaustão as razões que o levam a retratar estes personagens e suas circunstâncias" e ratifica que o cineasta não precisa se justificar: "nem ele nem qualquer criador/a LGBT". Com a dupla flexão de gênero aplicada ao item lexical "criador/a", Chelsea evoca Discursos inclusivos, que não apagam o gênero feminino. Logo conclui, referenciando, que "não é necessário fazer nenhum discurso. Basta que o que queira entender, entenda". Uma das possíveis interpretações deste fragmento remete à ambiguidade êmica do verbo entender, que em ambiente LGBT espanhol, assim como no Brasil, é muitas vezes usado para indexicalizar performances homoeróticas. De forma que aquelas/aqueles que desempenham tais performances (entendidas/ entendidos) compreenderiam as semioses em jogo.

Croissant inicia o sexto comentário referenciando que "de uma forma geral, os personagens de Almodóvar vivem situações limite, tanto LGBTs como heteros". Em seguida, qualifica de "solene idiotice" predicar os filmes de Almodóvar como "prejudiciais" à comunidade LGBT. O sétimo comentário, de Nelson, oferta um link que noticia a publicação do livro Cem personagens que denigrem Espanba, sendo o primeiro posto ocupado por Zapatero (ex-presidente) e o segundo, por Almodóvar. Nelson entextualiza, em forma de narrativa, a justificativa dada pela autora, Curri Valenzuela, para colocar o cineasta em tal posto: quando vai comprar o jornal em Nova York, o jornaleiro a encara com lascívia porque projeta uma identidade, por ela predicada como "depravada", a todas/todos que procedem da Espanha, o que,

17. Notável matemático, Turing criou um sistema de processamento de dados que colaborou para o desenvolvimento do computador. Submetido a tratamentos de 'cura homossexual', teria se suicidado aos 41 anos em 1954. Posteriormente foi condecorado pelo Império Britânico. 
segundo ela, deve-se aos filmes de Almodóvar. Eis aí outra transição escalar: tomase a performance de determinados personagens como traço cultural compartilhado por todas/todos aquelas/aqueles que procedem de um mesmo país. Logo, Nelson finaliza seu comentário colocando em escala de comparação o que Lan publicou com a argumentação de Valenzuela: ambas predicam as fachadas projetadas pelos filmes de Almodóvar como desfavoráveis. Lan porque julga que o cineasta se apoia em "estereótipos extremistas" ao retratar o coletivo LGBT e Valenzuela por compreender que Almodóvar posiciona as/os espanholas/espanhóis como pervertidos.

Iván, autor do oitavo comentário, concorda com Lan e critica Roberto por predicar Almodóvar como "valente", indagando "se há algo de positivo em relacionar homossexualidade e pedofilia", numa clara alusão à postagem deste, especificamente à menção ao dentista pedófilo, personagem do filme $\mathrm{O}$ que eu fiz para merecer isto? Nas entrelinhas de seu discurso, pode-se inferir que Iván, além de entender que Almodóvar não projeta uma boa fachada para o coletivo LGBT, também responsabiliza o cineasta por colaborar para que certos estigmas identitários, como o da pederastia, recaiam sobre aqueles que performam masculinidade homoerótica (MELERO SALVADOR, 2010).

Na sequência, Croissant novamente toma a palavra e entextualiza a cena de estupro de Kika, filme de Almodóvar, predicando o violador, que performa heterossexualidade, como "presidiário com pouco brilho". Logo questiona se um personagem assim não macularia a fachada do 'coletivo' heterossexual, pois prestaria um "desfavor" a este. Ao entextualizar o termo que Lan usa ("desfavor") para argumentar que o homoerotismo dos personagens de Almodóvar é nocivo para o coletivo LGBT, Croissant estabelece uma escala de comparação: sugere que, se assim fosse, o mesmo sucederia com o coletivo heterossexual, que teria sua fachada 'arranhada' pelo presidiário-estuprador de Kika. Este ponto, a comparação entre os efeitos de sentido produzidos por performances hetero e homossexuais em convergência com situações/práticas socialmente questionáveis, como um estupro, levam-nos a uma triste constatação: como algumas pessoas são compreendidas como mais humanas que outras (BUTLER, 2004), já que estigmas não recaem de igual maneira sobre todos os sujeitos. Nem na vida cotidiana (vide os marcadores sociais da diferença ${ }^{18}$ ), nem na ficção cinematográfica (o estuprador de Kika, por exemplo, escapa impune).

18. Embora aqui enfoquemos as interseções de gênero e sexualidade, entendemos que tais marcadores sociais da diferença, fruto de categorizações identitárias, também são interseccionados por performances de raça, classe etc. 
No último parágrafo de sua postagem, Croissant dirige-se a Nelson predicando como "almodovariana" a cena da jornalista Curri Valenzuela que, ao ir comprar o jornal em Nova York, sente-se interpelada por olhares de desejo lançados pelo jornaleiro.

Roberto, autor do texto "Pedro Almodóvar, pedagogo da realidade

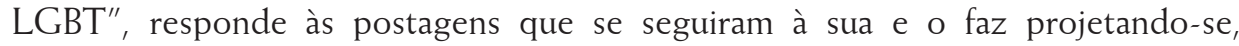
metapragmaticamente, como moderador. Em concordância com Napoleón, admite que alguns filmes de Almodóvar poderiam resultar escandalosos décadas depois de lançados. Logo ressalta que, ao publicar o texto que alavanca o debate, só emitiu sua opinião e que Lan "tem todo o direito a não estar de acordo", mas, ato seguido, discorda da/do participante, afirmando que sim, há personagens LGBT equilibrados nos filmes do cineasta. Em seguida, interpela Iván, que o recriminou por atribuir valentia a Almodóvar, e reafirma seu posicionamento referenciando que Almodóvar "pega algo que muitos utilizam para nos atacar e o apresenta com sinceridade e sem falsa moral". Tal movimento de Roberto encontra semelhança com a reapropriação do termo 'queer', que de insulto converte-se em palavra de afirmação e reivindicação no campo teórico-ativista (WILCHINS, 2004). Roberto também responde a CNTP e a Dill, agradece as contribuições e se despede.

\section{CONSIDERAÇÕES FINAIS}

Tanto a postagem como o debate online no site Dos Manzanas, como se pôde perceber nos excertos analisados, caracteriza-se por considerável engajamento argumentativo (daí a grande quantidade de respostas longas) e alta gama de entextualizações (tanto de citações prévias feitas por outras/outros participantes quanto de falas proferidas por personagens de Almodóvar). Há inclusive exemplos de como um texto, além de ser ressignificado ao adentrar novo contexto (BAUMAN \& BRIGGS, [1990] 2009), pode trair seu 'significado anterior', conforme sinalizado na análise. Também verifica-se considerável incidência de respostas multidirigidas numa mesma postagem, as quais se valem de vocativos para interpelar a mais de um/ uma destinatária(o). Isto aponta para uma peculiaridade nesta interação: o alto teor de reflexividade metapragmática que paira tanto sobre a pedagogia proposta como sobre os posicionamentos discursivos das/dos participantes. Tal reflexividade, reiteramos, é típica das múltiplas semioses que perpassam nossas práticas cotidianas e globalizadas, conforme se confirma na interação analisada.

Outro ponto que merece destaque são as frequentes transições escalares que pontuam a interação: participantes (Roberto, Napoleón, Lan, Croissant, Nelson), 
em uma mesma postagem, atravessam diferentes espaços-tempos. Tal constatação nos ajuda a entender a forma como 'identidades' são negociadas ali: estas, depois dos cerceamentos impostos por uma guerra civil e anos de ditadura franquista, precisavam ser reinventadas. Era necessário pensar novas formas de performar gênero e sexualidade. Personagens de Almodóvar apontaram caminhos em meio ao renascer democrático da Espanha, que se dá depois da morte de Franco em 1975, no poder desde a década de 30 . Por conta da magnitude das mudanças experimentadas, participantes frequentemente comparam espaços-tempos (exemplo: ditadura $\mathrm{x}$ democracia) de forma a contrastar os Discursos orientadores em circulação e as pragmáticas que estes inspira(va)m, tão díspares quanto o impacto da 'pedagogia almodovariana'. Esta, ao ser avaliada no site Dos Manzanas, coloca os personagens de Almodóvar em escala metonímica, convertendo-os em referentes LGBT.

No que diz respeito à maneira como esses referentes são avaliados no primeiro excerto, identifica-se que, mesmo qualificando-os positivamente, ao defender seu ponto de vista, Roberto os prefigura, incorrendo em simplificações defectivas (PINTO, 2013). Isto se torna claro quando ele delimita uma barreira entre performances de travestilidade e masculinidade homoerótica, essencializando ambas de forma nada estratégica: segundo ele, as primeiras são performadas porque quem se sente mulher, as outras, não. $\mathrm{E}$, ao mesmo tempo em que se queixa da invisibilidade homossexual e da falta de referentes, especialmente em um dado momento histórico (nos últimos anos do franquismo), apaga as 'identidades' travestis/transexuais ao não reconhecer como factível o desejo de seu amigo de colocar silicone nos seios, além de considerar apenas o efeito material da invisibilidade social para quem performa homoerotismo ("as carícias tinham que ser encobertas"). Seu posicionamento contradiz, ademais, outros dois pontos que, somados à luta pela diversidade, destacam-se dentre as reivindicações LGBT: igualdade e visibilidade para/dentre todas as 'identidades' que compõem a sigla. A dissonância entre o Discurso LGBT e o que jaz nas entrelinhas do discurso de Roberto evidencia as relações de poder que ali comparecem.

No segundo excerto, há tanto quem avalie positivamente algumas das performances não hegemônicas de gênero e sexualidade desempenhadas nos filmes de Almodóvar (Croissant, Chelsea e Nelson), como quem as reduza a estereótipos (Dill e Lan). Enquanto Lan avalia que os personagens LGBT do cineasta são "decadentes, engolidos pela droga e pela prostituição" e que, por conta disso, projetam uma fachada negativa para o coletivo LGBT, colaborando para que certos estigmas identitários permaneçam, Napoleón enaltece o "aporte capital para dar visibilidade ao âmbito LGBT e sua normalização". 
No entanto, as/os participantes não julgam apenas os personagens e suas performances. Há quem, caso de Napoleón, exija um posicionamento mais 'ativista' por parte de Almodóvar também em sua vida pessoal. Em contrapartida, Chelsea não reconhece a fachada de porta voz da causa LGBT que Roberto e Napoleón projetam sobre o cineasta. Fato é que este tipo de cobrança é usual no Dos Manzanas: muitas/muitos das/dos que interagem no site posicionam-se como ativistas que atuam em prol da causa LGBT e têm por hábito incentivar que figuras públicas igualmente o façam, sugerindo que se declarem L, G, B ou T, ou seja, que abracem uma identidade essencializada. Diferente do que Sedgwick ([1990] 2007) sinaliza, acreditam que é possível/necessário manter-se totalmente fora do armário sempre. Por conseguinte, exigem que todas/todos que, supostamente, desempenham performances associadas a uma das letras da sigla, posicionem-se publicamente com relação a isso.

$\mathrm{O}$ posicionar-se, que engloba o dizer-fazer, dimensionar-enquadrar, indexicalizar-interpretar, instruir-avaliar, entextualizar-ressignifiar, torna a pragmática indissociável da metapragmática. Esse, para Rajagopalan (2014, p. 3233), deveria ser foco de mais pesquisas no campo da linguagem: "o que importa mesmo não é como os 'fatos' realmente são, mas como eles são percebidos e efetivamente utilizados nas práticas sociais". Indispensável recordar, ademais, que são as diferentes formas de se produzir sentido sobre performances/práticas, ou seja, as diferentes metapragmáticas em disputa, que podem nos levar a desconstruir categorias estanques. Tendo-o em tela, debruçamo-nos sobre a postagem de Roberto e a interação que esta suscita focando na reflexividade metapragmática que permeia os dois excertos. Em linhas gerais, identifica-se maior preocupação com a forma como as 'identidades' são projetadas e socialmente valoradas do que com a busca/produção de outras performatividades de gênero e sexualidade possíveis. Há mais essencialismo que estratégia nos usos políticos da identidade observados na interação, que os tornam diferentes do "essencialismo estratégico", defendido por Spivak (1988). Isso resulta problemático porque essencialismos imobilizam o sujeito sociolinguisticamente, estereotipificam formas de existir/estar no mundo, colaborando para reificar Discursos dos quais as pessoas precisam se livrar para se reinventarem (MOITA LOPES, 2013b). Precisamente por essa razão, urge "melhor situar o discurso ativista" (BIONDO \& SIGNORINI, 2015, p. 194) e fomentar o diálogo entre uma academia mais politizada e comprometida com a reinvenção da vida social e vertentes do ativismo LGBT que se apoiam em concepções engessadas acerca do gênero e da sexualidade. Talvez áreas de investigação mais responsivas para com a vida social, tal como a Linguística Aplicada Indisciplinar se propõe a 
ser (MOITA LOPES, [2006] 2016), logrem produzir novas pontes semióticoepistemológicas que apontem um caminho possível que ajude a queerizar o ativismo LGBT.

\section{REFERÊNCIAS}

ARNALTE, A. (2003). Redada de violetas: La represión a bomosexuales durante el franduismo. Madri: La esfera de los libros.

BAUMAN, Z. (2001). Modernidade Líquida. Tradução de Plínio Dentzien. Rio de Janeiro: Jorge Zahar.

BAUMAN, R.; BRIGGS, C. (1990). Poetics and performance as critical perspectives on language and social life. In: COUPLAND, $\mathrm{N}_{i}$ JAWORSKI (Eds.). The new sociolinguistics reader. New York: Palgrave Macmillan, 2009.

BAUMAN, R. \& BRIGGS, C. (2003). Voices of modernity: Language ideologies and the politics of inequality. Cambridge: CUP.

BERGMAN, J.R. (1998). Introduction: Morality in Discourse. Research on Language and Social Interaction, 31: 3-4, p. 279-294.

BIONDO, F.P.; SIGNORINI, I. (2015). (Re)definições e (des)construções identitárias em comunidades ativistas do Facebook: contribuições das epistemologias pós-feminista e queer. DELTA, v. 31, p. 6-s/n.

BLOMMAERT, J. (2005). Discourse: a critical introduction. Cambridge: CUP.

BLOMMAERT, J. (2010). The sociolinguistics of globalization. Cambridge: CUP.

BLOMMAERT, J. \& RAMPTON, B. (2011). Language and Superdiversity. Diversities, 13(2), p. $1-21$.

BORBA, R. (2015). Linguística queer: uma perspectiva pós-identitária para os estudos da linguagem. Revista Entrelinbas, Vol. 9, n. 1 (jan./jun.), p. 91-107.

BUCHOLTZ, M. \& HALL, K. (2004). Theorizing identity in language and sexuality research. Language in Society, 33: p. 469-515.

BUTLER, J. (1990) Gender Trouble: Feminism and the Subversion of Identity. London: Routledge. 
BUTLER, J. (1999). "Corpos que pesam: sobre os limites discursivos do 'sexo". In: LOURO, G.L. (Org.), O corpo educado: pedagogias da sexualidade. Traduções de Tomaz Tadeu da Silva. Belo Horizonte: Autêntica, p. 151-172.

BUTLER, J. (2004). Undoing gender. New York: Routledge.

BUTLER, J. (2005). Relatar-se a si mesmo: Crítica da violência ética. Tradução de Rogério Bettoni. Belo Horizonte: Autêntica, 2015.

CAMERON, D. \& KULICK, D. (2003). Language and sexuality. Cambridge: CUP.

CARR, E.S.; LEMPERT, M. (2016) Scale: discourse and dimensions of social life. Oakland: University of California Press.

FELLIPE, R.F. (2004). Silêncio e (meta)linguagem em "Fale com ela". Cadernos Pagu, (23), p. 399-411.

FOUCAULT, M. (1969). A Arqueologia do Saber. Tradução de Luiz Felipe Baeta Neves. [7. ed.] Rio de Janeiro: Forense Universitária, 2008.

FOUCAULT, M. (1976). História da sexualidade: a vontade de saber vol. I. Tradução de Maria Thereza da costa Albuquerque e J. A. Guilhon Albuquerque. Rio de Janeiro: Graal, 1999.

FOUCAULT, M. (1984). História da sexualidade: os usos do prazer vol. II. Tradução de Maria Thereza da costa Albuquerque. Rio de Janeiro: Graal, 1998.

FOUCAULT, M. (1972) Microfísica do poder. Tradução e organização de Roberto Machado. Rio de Janeiro: Graal, 1984.

FOUCAULT, M. (2010). O sujeito e o poder. In: DREYFUS, H. \& RABINOW, P. (Eds.), Michel Foucault: uma trajetória filosófica. Tradução de Vera Porto Carrero. Rio de Janeiro: Forense Universitária.

GEE, J.P. (1990). Social linguistics and Literacies. Ideology in discourses. London: Falmer Press.

GEE, J.P. (2004). Situated Language Learning: A Critique of Traditional Schooling. New York: Routledge.

GIDDENS, A.; BECK, U. \& LASH, S. (1997). Modernização reflexiva: política, tradição e estética na ordem social moderna. Tradução de Magda Lopes. São Paulo: Unesp. 
GOFFMAN, E. (1967). Ritual de interação: Ensaios sobre o comportamento face a face. Tradução de Fábio R. Ribeiro da Silva. Petrópolis: Editora Vozes, 2011.

GOFFMAN, E. (1979). Footing. In: RIBEIRO, B.T. \& GARCEZ, P.M. (Orgs.), Sociolinguística interacional. São Paulo: Edições Loyola, 2002.

GONZALEZ, C. \& MOITA LOPES, L. P. (2015). Posicionamentos interacionais mobilizados por Tudo sobre minha mãe na rede social Filmow. DELTA, 31-2, p. 473-503.

GONZALEZ, C. \& MOITA LOPES, L. P. (2016). Performance narrativa multimodal de Agrado em Tudo sobre minha mãe: desarticulando a autenticidade de gênero. RBLA, Belo Horizonte, v. 16, nº. 4, p. 679-708.

HALL, K. (2013). "It's a hijra!": queer linguistics revisited. Discourse \& society, 24 (5), p. 634 642.

JACQUEMET, M. (2005). Transidiomatic practices: Language and power in the age of globalization. Language \& Communication, 25, p. 257-277.

JENKINS, H. (2008). Cultura da convergência. São Paulo: Aleph.

MELERO SALVADOR, A. (2010). Placeres ocultos: Gays y lesbianas en el cine español de la transición. Madrid: Notorious.

MELO, G.C.V. \& MOITA LOPES, L.P. (2014). Ordens de indexicalidade mobilizadas nas performances discursivas de um garoto de programa: ser negro e homoerótico. Linguagem em (Dis) curso, v. 14, $\mathrm{n}^{\circ} 3$, p. 653-685.

MISKOLCI, R. (2011). Não somos, queremos - Reflexões queer sobre a política sexual brasileira contemporânea. In: COLLING, L. (Org.), Stonewall $40+$ o que no Brasil. Salvador: EDUFBA.

MOITA LOPES, L.P. (2006). Por uma Linguística Aplicada Indisciplinar. São Paulo: Parábola, 2016.

MOITA LOPES, L.P. (2013a). O português no século XXI: Cenário geopolítico e sociolinguístico. São Paulo: Parábola editorial.

MOITA LOPES, L.P. (2013b). Linguística Aplicada na Modernidade Recente. Festschrift para Antonieta Celani. São Paulo: Parábola. 
MOITA LOPES, L.P. (2015). Global Portuguese. Linguistic ideologies in late modernity. New York: Routledge.

OSTERMANN, A.C. (2003). Communities of practice at work: gender, facework and the power of habitus at an aff-female police station and a feminist crisis intervention center in Brazil. Discourse \& Society, 14 (4), p. 474-505.

PENNYCOOK, A. (2007). Global Englishes and Transcultural Flows. New York: Routledge.

PINTO, J.P. (2013). Estranhar o conhecimento familiar, resistir às identidades normativas. In: PINTO, J.P.; FABRÍCIO, B.F. (Orgs.). Exclusão social e microrresistências-a centralidade das práticas discursivo-identitárias. Goiânia: Cânone Editorial.

PRECIADO, P. (2003). Multidões queer: nota para uma política dos 'anormais'. Estudos Feministas, Florianópolis, 19(1), 2011/janeiro-abril, p. 11-20.

RAJAGOPALAN, K. Da arrogância cartesiana à "nova pragmática" (Prefácio). In: SILVA, D.; FERREIRA, D. \& ALENCAR, C. (Orgs.), Nova pragmática: Modos de fazer. São Paulo: Cortez, 2014.

SEDGWICK, E. (1990). A epistemologia do armário. Cadernos Pagu, 28, 2007, p. 19-54.

SILVA, D.; FERREIRA, D.; ALENCAR, C. (2014). Nova pragmática: Modos de fazer. São Paulo: Cortez.

SILVERSTEIN, M. (2003). Indexical order and the dialectics of sociolinguistic life. Language \& Communication, 23, p. 193-229.

SILVERSTEIN, M. \& URBAN, G. (1996). Natural bistories of discourse. Chicago: The University of Chicago Press.

SPIVAK, G.C. (1988). Subaltern Studies: Deconstructing Historiography. In: GUHA, R. \& SPIVAK, G.C. (Eds.), Selected Subaltern Studies. Oxford: OUP.

VELOSO, M.T. (2012). O sujeito do desejo na trama do discurso. Frederico Westphalen: URIFrederico Westph.

VERTOVEC, S. (2007). Superdiversity and its implications. Ethnic and Racial Studies, Vol. 30, No. 6, p. 1024-1054.

WILCHINS, R. (2004). Queer theory, gender theory. Los Angeles: Alysson Books. 
WORTHAM, S. (2005). Socialization beyond the speech event. Journal of Linguistic Anthropology, v. 15, nº1, p. 95-112.

Recebido: 23/11/2017

Aceito: 18/07/2018 